\title{
Potensi Dampak Perubahan Iklim Terhadap Produksi Ubi Kayu (Manihot esculenta Crantz) dan Pendapatan Petani di Desa Wain, Kecamatan Kei Kecil Timur, Kabupaten Maluku Tenggara
}

\section{Potential Impacts of Climate Change on Cassava (Manihot esculenta, Crantz) Production and Farmers' Income in Wain Village, Kei Kecil Timur District, Southeastern Maluku Regency.}

\author{
Anastasia Wokanubun ${ }^{1}$, Anna Y. Wattimena ${ }^{2}$, Rhony E. Ririhena ${ }^{1, *}$ \\ ${ }^{1)}$ Program Studi Agroteknologi, Jurusan Budidaya Pertanian, Fakultas Pertanian, Universitas Pattimura, Jl. Ir. M. \\ Putuhena Kampus, Poka Ambon 97233, Indonesia \\ ${ }^{2)}$ Jurusan Budidaya Pertanian, Fakultas Pertanian, Universitas Pattimura, Jl. Ir. M. Putuhena, Kampus Poka Ambon \\ 97233, Indonesia \\ *E-mail Penulis Korespondensi: reririhena@gmail.com
}

\begin{abstract}
One of the environmental factors that affect cassava productivity is climate/weather. Climate change has the potential to have an impact on various sectors, one of which is the food crop sector. Cassava is one of the local food commodities in Ohoi Wain that is at risk of being affected by the impact of climate change. This study aimed to identify the dominant climate factors affecting cassava production, assess farmers' adaptation strategies to climate change and analyze the impact of climate change on production and farmers' income. The method used was descriptive analysis method used to analyze the dominant climate factors affecting the production of cassava and the adaptation strategy adopted by farmers, algebraic averaging technique for rainfall analysis, quantitative analysis for analyzing farmers' income and regression equations to see the relationship between rainfall and cassava productivity. The results showed that the climatic factor that most dominantly influenced the production of cassava was rainfall. The adaptation made by farmers to climate change was by changing planting time, minimum tillage, selecting superior varieties and applying organic mulch. Climate change, marked by a decrease in rainfall in 2015, caused the productivity of cassava to decrease by $46,4 \%$ and farmers' income to increase by $11,45 \%$. The decrease in rainfall had a very significant effect on the decrease in the productivity of cassava or had a strong relationship, which was shown by the correlation coefficient value $r=0,04731$ and a high level of accuracy with $R 2=89,2 \%$.
\end{abstract}

Keywords: adaptation, climate change, cassava production, income

\section{ABSTRAK}

Salah satu faktor lngkungan yang berpengaruh terhadap produktivitas ubi kayu adalah iklim/cuaca. Perubahan iklim berpotensi untuk memberikan dampak pada berbagai macam sektor, salah satunya adalah sektor tanaman pangan . Ubi kayu merupakan salah satu komuditas pangan lokal di Ohoi Wain yang beresiko terpengaruh dampak perubahan iklim. Penelitian ini bertujuan untuk mengidentifikasi faktor iklim yang dominan mempengaruhi produksi ubi kayu, mengkaji strategi adaptasi petani terhadap perubahan iklim dan menganalisis dampak perubahan iklim terhadap produksi dan pendapatan petani. Metode yang digunakan adalah metode analisis deskriptif, digunakan untuk menganalisis faktor iklim yang dominan mempengaruhi produksi ubi kayu dan strategi adaptasi yang dilakukan petani. Teknik rata-rata aljabar digunakan untuk analisis curah hujan, Analisis kuantitatif digunakan untuk menganalisis pendapatan petani dan persamaan regresi untuk melihat hubungan antara curah hujan dan produktivitas ubi kayu. Hasil penelitian menunjukkan bahwa faktor iklim yang paling dominan mempengaruhi produksi ubi kayu adalah curah hujan. Adaptasi yang dilakukan oleh petani terhadap perubahan iklim adalah dengan melakukan perubahan waktu tanam, pengolahan tanah minimum, pemilihan variatas unggul dan penggunaan mulsa organik. Perubahan iklim yang ditandai dengan penurunan curah hujan pada tahun 2015 menyebabkan produktivitas ubi kayu mengalami penurunan sebesar 46,4\% dan pendapatan petani mengalami peningkatan sebesar 11,45\%. Penurunan curah hujan berpengaruh sangat nyata terhadap penurunan produktivitas ubi kayu atau memiliki keeratan hubungan yang kuat, yang ditunjukan oleh nilai koefisien korelasi $r=0,04731$ dan tingkat akurasi yang tinggi dengan $\mathrm{R}^{2}=89,2 \%$.

Kata kunci: adaptasi, pendapatan, perubahan iklim, produksi ubi kayu 


\section{PENDAHULUAN}

Ubi kayu pahit enbal (Manihot esculenta Crantz) merupakan komoditas pangan lokal masyarakat Maluku Tenggara. Pangan lokal adalah pangan yang diproduksi dan dikembangkan sesuai dengan potensi sumber daya wilayah dan budaya setempat. Pangan lokal merupakan yang sudah dikenal, mudah diperoleh, beragam jenisnya, bukan diimpor dan dapat diusahakan untuk memenuhi kebutuhan sendiri atau dijual. Setiap daerah memiliki keunggulan pangan lokal yang berbeda sesuai dengan tingkat produksi dan konsumsi. (Muctadi dan Sugiyono, 1992).

Tapotubun (2012) melaporkan bahwa sentra produksi ubi kayu di daerah Maluku Tenggara berada di Ohoi Wain. Ohoi Wain merupakan salah satu ohoi yang berada di pesisir Kecamatan Kei-Kecil Timur, Kabupaten Maluku Tenggara, dengan jumlah penduduk \pm 1.133 jiwa; dengan mata pencaharian penduduk yang umumnya petani. Ohoi Wain selama ini juga seperti beberapa ohoi pesisir lainnya yang memiliki sumberdaya laut maupun sumberdaya pertanian khususnya enbal (dalam bahasa daerah Kei) atau lebih dikenal dengan ubi kayu. Budidaya ubi kayu telah lama dilakukan oleh petani di Ohoi Wain secara turun temurun dengan cara tradisional.

Ubi kayu sebagai pangan lokal, dijadikan alternatif pilihan, yaitu sebagai pengganti beras/nasi untuk antisipasi kerawanan pangan di masa mendatang. Selain sebagai pangan lokal, ubi kayu dapat diolah menjadi aneka macam produk yang dapat dipasarkan, seperti enbal bungkus, enbal bunga, enbal kacang, enbal keju, enbal stik dan lain sebagainya. Potensi usaha ubi kayu yang sangat besar ini kemudian oleh Pemerintah Kabupaten Maluku Tenggara pada tahun 2014 diberikan bantuan 60 ha area untuk penanaman ubi kayu kepada Ohoi Wain. Bantuan yang diberikan tersebut merupakan tindak lanjut pemerintah kabupaten dalam menyukseskan salah satu tujuan dari RPJMD Kabupaten Maluku Tenggara, dalam rangka menyuarakan kepada masyarakat kembali mengkonsumsi enbal dengan salah satu programnya, yaitu one day no rice. Kebijakan tersebut merupakan salah satu peluang bagi petani untuk meningkatkan produksinya.

Permasalahan umum pada pertanaman ubi kayu adalah produktivitas dan pendapatan yang rendah. Produktivitas suatu tanaman bergantung pada interaksi yang terjadi antara faktor lingkungan dan genetik. Salah satu faktor lngkungan yang berpengaruh terhadap produktivitas ubi kayu adalah iklim/cuaca. Interaksi antara iklim/cuaca sebagai faktor lingkungan dengan faktor genetik tanaman akan berpengaruh terhadap pertumbuhan dan kualitas tanaman. Faktor genetik berkaitan dengan karakteristik yang biasanya bersifat khas pada tanaman, seperti kondisi batang, bentuk bunga, bentuk daun dan sebagainya. (Thamrin et al 2013).

Iklim perlu mendapat perhatian yang lebih serius mengingat pengaruhnya terhadap hampir semua aspek pertanian, sehingga sangat berperan terhadap perencanaan jangka pendek maupun jangka panjang, terlebih lagi pada kondisi terjadinya perubahan iklim atau kejadian iklim ekstrim. Kejadian perubahan iklim sebagaimana diproyeksikan oleh model-model iklim abad 21 mempunyai potensi secara signifikan mengubah kondisi produksi (Anwar et al. 2015). IPCC (2007) menjelaskan bahwa curah hujan rata-rata global meningkat $2 \%$ dalam 100 tahun terakhir. Ruminta et al. (2018), melaporkan Selama abad terakhir, perubahan iklim telah menyebabkan kenaikan suhu global, pergeseran pola curah hujan, muka air laut meningkat, serta frekuensi dan intensitas cuaca ekstrim meningkat.

Terjadinya iklim ekstrim berdampak cukup besar terhadap tanaman semusim, terutama tanaman pangan. Salah satu unsur iklim yang dapat digunakan sebagai indikator dalam kaitannya dengan tanaman adalah curah hujan. Mengingat curah hujan merupakan unsur iklim yang fluktuasinya tinggi dan pengaruhnya terhadap produksi tanaman cukup signifikan. Peningkatan curah hujan di suatu daerah berpotensi menimbulkan banjir, sebaliknya jika terjadi penurunan dari kondisi normalnya akan berpotensi terjadinya kekeringan. Kedua hal tersebut tentu akan berdampak buruk terhadap metabolisme tubuh tanaman dan berpotensi menurunkan produksi, hingga kegagalan panen. (Suciantini,2015)

Anwar et al. 2015 melaporkan bahwa jumlah curah hujan secara keseluruhan sangat penting dalam menentukan hasil terlebih apabila ditambah dengan peningkatan suhu, peningkatan suhu yang besar dapat menurunkan hasil. Peningkatan suhu menyebabkan terjadinya peningkatan transpirasi yang selanjutnya menurunkan produktivitas tanaman pangan (Las, 2007).

Menurut Latiri et al (2010), curah hujan berkorelasi tinggi terhadap komponen hasil, sejalan dengan DiFalco et al (2010) yang melaporkan bahwa sejumlah tanaman berkorelasi positif dengan curah hujan. Studi Latiri et al (2010) di Tunisia, menunjukkan bahwa komponen hasil sangat dipengaruhi oleh kondisi curah hujan pada musim gugur, yang menunjukkan pentingnya tahap pertumbuhan awal. Air merupakan faktor pembatas utama di wilayah semi arid, hal itu ditunjukkan tidak saja oleh produksi per hektarnya, tetapi juga oleh total luas panen.

Di Maluku Tenggara perubahan pola hujan adalah ancaman yang besar, karena begitu banyak petani mengandalkan langsung pada hujan untuk kegiatan pertaniannya. Setiap perubahan curah hujan menyebabkan resiko besar. Pertanian tadah hujan sangat rentan terhadap perubahan iklim, jika praktek bertani tetap tidak berubah. Untuk itu diperlukan langkah antisipasi atau upaya-upaya yang dilakukan petani dengan tujuan melakukan penyesuaian terhadap dampak dari perubahan iklim untuk mengurangi resiko kegagalan produksi pertanian .

Kebijakan terkait perubahan iklim terhadap sektor pertanian di Indonesia lebih difokuskan pada komuditas padi. Kebijakan mengenai produksi komoditi lain, seperti ubi kayu, atau hubungan komoditi dengan 
lokasi dengan budaya spesifik lokal masih sangat jarang. Di sisi lain dampak perubahan iklim yang dikeluarkan oleh Kementrian Pertanian (2001) bersifat multidimensi, mulai dari sumber daya, infra struktur pertanian, sistem produksi pertanian, aspek ketahanan dan kemandirian pangan, serta kesejateraan masyarakat petani. Artinya petani komoditas non-padi yang dalam penelitian ini dispesifikasikan pada petani pangan umbian, khususnya ubi kayu di daerah kering wilayah pulau kecil layak dikaji untuk mengetahui tingkat kerentanannya terhadap perubahan iklim, sehingga dapat memberikan arahan kebijakan dalam upaya menghadapi tantangan dan peluang perubahan iklim yang lebih komprehensif pada wilayah berkarakteristik pulau kecil, seperti di Kabupaten Maluku Tenggara, Provinsi Maluku.

Perubahan iklim berpotensi untuk memberikan dampak pada berbagai sektor, salah satunya adalah sektor tanaman pangan. Ubi kayu merupakan salah satu komuditas pangan lokal di Ohoi Wain yang beresiko terpengaruh dampak perubahan iklim. Dampak perubahan iklim tidak hanya berpengaruh pada aktifitas produksi tetapi juga terhadap pendapatan petani ubi kayu. Sampai sekarang penelitian mengenai dampak perubahan iklim terhapad produksi pangan lokal, terutama enbal, di wilayah pulau-pulau kecil di Kabupaten Maluku Tenggara serta dampaknya terhadap pendapatan petani dan serta bagaimana upaya petani dalam menghadapinya belum dilakukan. Sehingga perlu mengkaji potensi dampak perubahan iklim terhadap produksi ubi kayu dan pendapatan petani.

Penelitian ini bertujuan untuk: 1) menganalisis faktor iklim yang lebih dominan mempengaruhi produksi ubi kayu, 2) mendiskripsikan upaya yang dilakukan petani dalam menghadapi perubahan iklim, 3) menganalisis dampak perubahan iklim terhadap hasil produksi ubi kayu dan pendapatan petani.

\section{BAHAN DAN METODE}

\section{Tempat dan Waktu Penelitian}

Penelitian ini dilakukan di Desa Wain, Kecamatan Kei Kecil Timur, Kabupaten Maluku Tenggara dari bulan Agustus sampai September 2019.

\section{Bahan dan Alat Penelitian}

Bahan yang digunakan dalam penelitian ini adalah data iklim (curah hujan, lama hari hujan, suhu, kelembapan) dan data hasil wawancara. Sedangkan alat yang digunkan adalah: seperangkat laptop yang dilengkapi dengan perangkat lunak Microsoft Office, kuisioner, alat tulis menulis, camera dan lain-lain.

\section{Metode penelitian}

Pada penelitian ini pengumpulan dan analisis data dilaksanakan sebagai berikut:
1. Pemgumpulan data berupa data iklim yang diperoleh dari Stasiun Meteorologi Dumatubun Tual berupa data curah hujan periode pengamatan 30 tahun terakhir (1989-2018); data unsur iklim lainnya (suhu udara, kelembaban udara, penyinaran matahari, dan angin); data luas areal tanam, luas panen dan produksi/produktivitas ubi kayu dalam 10 tahun terakhir (2009-2018) hasil wawancara dengan petani ubi kayu di Desa Wain menggunakan kuisioner serta data BPS.

2. Analisis data terdiri dari analisis deskriptif untuk menganalisis faktor iklim yang dominan mempengaruhi produktivitas ubi kayu dan upaya adaptasi yang dilakukan petani, analisis data curah hujan menggunakan teknik rata-rata aljabar, analisis kuantitatif untuk menganalisis pendapatan petani serta analisis hubungan curah hujan dengan produktivitas tanaman menggunakan persamaan regresi sederhana.

\section{HASIL DAN PEMBAHASAN}

\section{Perubahan Iklim Di Pulau Kei Kecil}

Dalam bidang pertanian, perubahan iklim yang terjadi hingga saat ini dan terus akan berlanjut berdampak langsung terhadap ketersediaan air tanah dan berdampak lanjut terhadap luas tanam, luas panen dan produksi pertanian, serta banjir/longsor/genangan. Di samping itu, dampak lain dari perubahan iklim adalah terhadap perkembangan organisme pengganggu tanaman; dimana suhu yang semakin tinggi akan memicu perkembangan beberapa hama dan penyakit tanaman (Laimeheriwa, 2014).

Terkait dengan perubahan iklim, dua unsur iklim utama yang umumnya dibicarakan atau dikaji berbagai pihak adalah suhu udara dan curah hujan. Berikut ini akan dibahas perubahan suhu udara dan distribusi curah hujan tahunan yang terjadi di Pulau Kei Kecil.

\section{Perubahan suhu udara}

Berdasarkan hasil pengolahan data observasi BMKG tahun 1981-2018, secara umum suhu di Indonesia baik suhu minimum, rata-rata, dan maksimum memiliki kecenderungan yang bernilai positif dengan besaran yang bervariasi rata-rata $0.03^{\circ} \mathrm{C}$ setiap tahunnya. Ini bisa diartikan bahwa suhu akan mengalami kenaikan $0.03{ }^{\circ} \mathrm{C}$ setiap tahunnya sehingga dalam 30 tahun lokasi tersebut akan mengalami kenaikan sebesar $0.9^{\circ} \mathrm{C}$ (BMKG, 2019).

Hasil analisis menunjukkan bahwa perubahan suhu udara di Pulau Kei Kecil dalam periode 30 tahun terakhir (1989-2018) cenderung meningkat setiap tahunnya sebesar $0,0176^{\circ} \mathrm{C}$ (Gambar 3). Diproyeksikan pada 30 tahun mendatang suhu udara di wilayah ini akan mengalami kenaikan sebesar $0,53^{\circ} \mathrm{C}$. Adanya kecenderungan peningkatan suhu udara ini akan berdampak pada terjadinya peningkatan deplesi air 
tanah akibat meningkatnya evapotranspirasi. Kondisi ini berisiko terhadap berkurangnya ketersediaan air tanah terutama ketika dibarengi dengan kejadian kekeringan (kemarau panjang) atau anomali iklim El-Nino. Di samping itu, diperkirakan akan terjadi eksploitasi beberapa organisme pengganggu tanaman yang akan berpengaruh negatif terhadap hasil tanaman.

\section{Distribusi curah hujan tahunan}

Hasil analisis data curah hujan 30 tahun terakhir (1989-2018) menunjukkan bahwa curah hujan tahunan di Pulau Kei Kecil berkisar antara yang paling kering $1.863 \mathrm{~mm}$ pada tahun 1997 hingga yang paling basah $4.039 \mathrm{~mm}$ pada tahun 2010, dengan nilai rata-rata curah hujan tahunan (normal) sebesar $2.716 \mathrm{~mm}$ (Gambar 4).

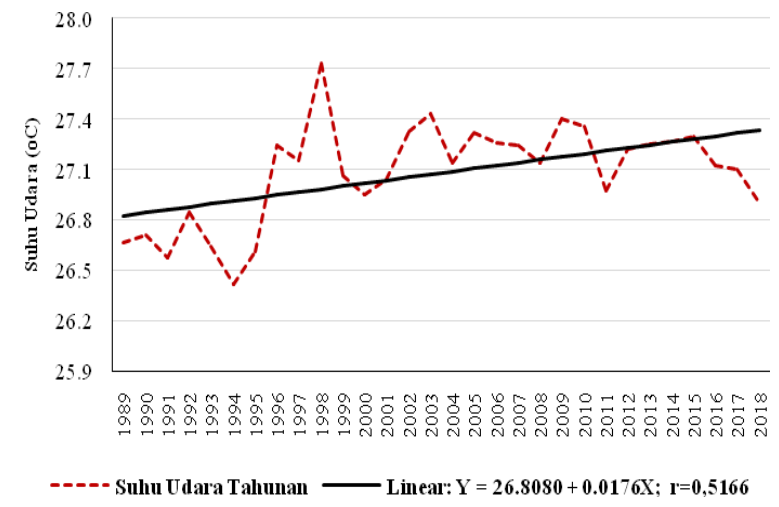

Gambar. 3 Tren perubahan suhu udara di Pulau Kei Kecil

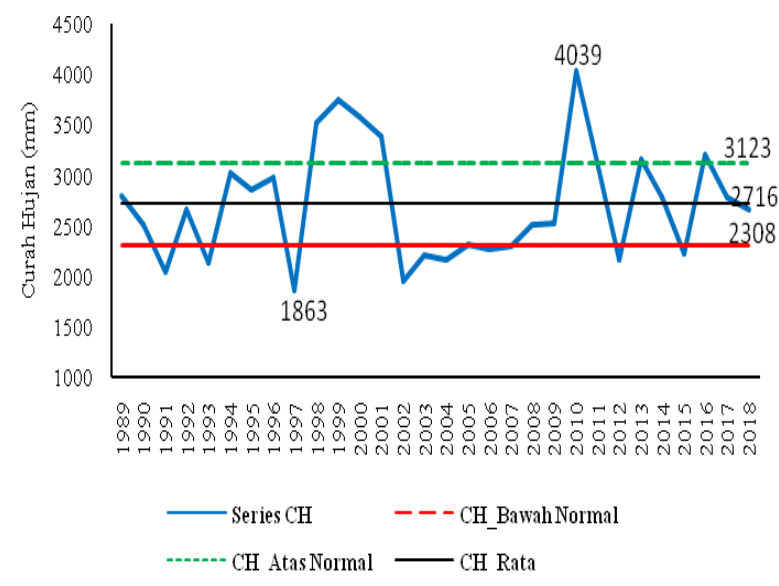

Gambar 4. Distribusi curah hujan $(\mathrm{CH})$ tahunan Pulau Kei Kecil.

Nampak pada Gambar 4 bahwa selama periode 30 tahun (1989-2018) telah terjadi penyimpangan curah hujan di atas kondisi normalnya sebanyak 8 kali, yaitu pada tahun: 1998, 1999, 2000, 2001, 2010, 2013, dan 2016. Selanjutnya penyimpangan curah hujan di bawah kondisi normal sebanyak10 kali, yaitu pada tahun: 1991, 1993, 1997, 2002, 2003, 2004, 2006, 2007, 2012, dan 2015. Dengan demikian dalam periode 30 tahun tersebut, sebanyak $60 \%$ telah terjadi penyimpangan curah hujan dari kondisi normalnya, sementara curah hujan berada pada selang normalnya sebanyak 40\% (12 tahun), yaitu tahun: 1989, 1990, 1992, 1994, 1995, 1996, 2005, 2008, 2009, 2014, 2017, dan 2018.

Berdasarkan data penyimpangan curah hujan tersebut dapat dikatakan bahwa pada kondisi curah hujan dibawah normal sangat berisiko terhadap kejadian kekeringan atau kekurangan air. Sebaliknya, kondisi curah hujan diatas normal berisiko terhadap kejadian banjir/genangan akibat kelebihan air.

\section{Faktor Iklim yang Dominan Mempengaruhi Produksi Ubi Kayu}

Responden yang terlibat dalam penelitian ini pada umumnya mengetahui bahwa curah hujan, suhu, dan kelembaban merupakan faktor iklim yang berpengaruh dalam usaha tani ubi kayu. Dari 30 responden yang diwawancarai, $76,6 \%$ responden menyatakan bahwa curah hujan lebih berpengaruh terhadap hasil produksi ubi kayu, karena sistem pertanian yang mereka lakukan merupakan sistem pertanian yang dilakukan pada lahan kering yang hanya mengandalkan air hujan. Akibatnya jika tidak ada hujan pada saat proses penanaman, stek batang yang ditanam akan kering dan mati. Selain itu jika curah hujan tinggi pada saat tanaman memasuki waktu panen, akan mempengaruhi kandungan air di dalam umbi. Umbi yang dipanen banyak mengandung air sehingga hasil produksi menurun. Di sisi lain $23,3 \%$ responden menyatakan bahwa selain curah hujan, suhu juga mempengaruhi produksi ubi kayu. Responden menjelaskan pada saat suhu meningkat terlalu tinggi akan menyebabkan tanaman terserang hama penyakit, pucuk daun kering, keriting dan layu.

\section{Upaya Petani dalam Menghadapi Perubahan Iklim}

Perubahan iklim yang ditandai dengan adanya penurunan curah hujan dapat mengakibatkan penurunan produksi dan produktivitas tanaman ubi kayu. Oleh sebab itu, perlu dilakukan adaptasi untuk meminimalkan kehilangan hasil. Berdasarkan hasil wawancara dengan petani responden, petani yang malakukan adaptasi terhadap perubahan iklim sebanyak $43,3 \%$, sedangkan $56,6 \%$ tidak melakukan adaptasi. Upaya yang dilakukan petani di Ohoi Wain untuk meminimalkan kehilangan hasil diantaranya :

1. Pengolahan tanah minimum untuk mengurangi evaporasi karena permukaan tanah terbuka.

2. Mengubah waktu tanam, yaitu petani menjelaskan bahwa penanaman ubi kayu biasanya dilakukan pada bulan Oktober sekitar tanggal 1-10 karena pada kisaran tanggal tersebut biasanya ada hujan, tetapi karena iklim terkadang tidak menentu sehingga petani mengubah waktu tanam ke bulan November.

3. Melakukan pemilihan varietas tanaman yang unggul dan toleran terhadap cekaman kekeringan, serta berumur pendek sebagai antisipasi fenomena 
terjadinya El-Nino. Variatas yang tahan terhadap cekaman kekeringan dan sering ditanam oleh petani adalah varitas Bintang Wain.

4. Pemberian mulsa organik yang tersedia setempat untuk mengurangi evapotranspirasi dan menjaga kelembaban tanah serta meningkatkan kesuburan tanah. Mulsa organik diperoleh dari sisa-sisa penyiangan ditebar diatas bagian perakaran tanaman.

\section{Hubungan Curah Hujan dan Produktivitas}

Analisis koefisien korelasi menunjukan hubungan korelasi yang sangat erat antara variabel curah hujan terhadap produktivitas ubi kayu yaitu sebesar 0,876. Nilai determinasi $\mathrm{R}^{2}$ adalah sebesar 0,916 , artinya curah hujan memberikan kontribusi sebesar 0,916 terhadap produktivitas ubi kayu, sedangkan 0,084 ditentukan oleh faktor lain. Persamaan regresi kuadratik menunjukan bahwa produksi ubi kayu tahunan pada selang waktu 10 tahun terakhir (20092018) dipengaruhi oleh curah hujan (dengan koefisien $+0,04731$ ). Koefisien bernilai positif artinya menunjukan hubungan positif antara curah hujan dengan produksi, semakin tinggi curah hujan maka semakin tinggi produksi. Hubungan curah hujan dan produktivitas disajikan pada Gambar 12.

\section{Produksi Ubi Kayu}

Produksi ubi kayu adalah seluruh produksi total yang dihasilkan pada musim tanam periode atau tahun tertentu. Sedangkan produktivitas ubi kayu didapatkan dari perhitungan produksi total dibagi luas panen musim tanam tahun tertentu. Tabel 3 menjelaskan luas tanam, luas panen, produksi dan produktivitas ubi kayu di Kabupaten Maluku Tenggara.

Berdasarkan hasil penelitian, jumlah responden yang memiliki luas areal tanam ubi kayu $<0,1$ ha sebanyak 33,3\%, untuk luas areal tanam $0,1-0,2$ ha sebanyak $33,3 \%$ dan responden yang memiliki luas areal tanam $>0,2$ ha sebanyak $33,3 \%$. Produksi yang dihasilkan petani pada masing-masing luas areal tanam tersebut berbeda-beda (Tabel 4). Sebagaimana ditunjukkan pada Tabel 5, total produksi ubi kayu di Ohoi Wain pada kondisi iklim normal, yaitu pada tahun 2014 mencapai 82 ton, sedangkan produksi pada kondisi iklim ekstrim, yaitu pada tahun 2015 menurun menjadi 44 ton.

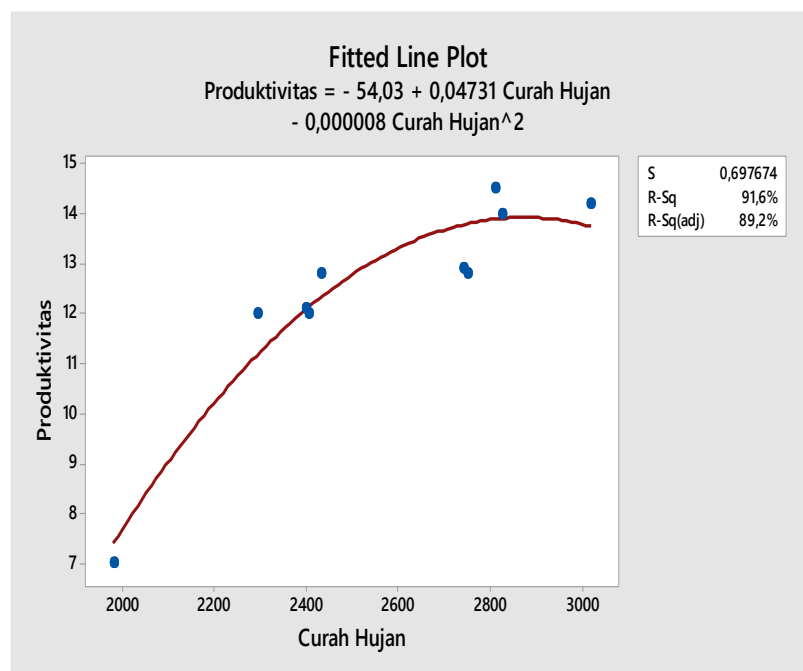

Sumber: Data primer diolah, 2020.

Gambar 12. Hubungan curah hujan dan produktivitas ubi kayu

\section{Penilaian Responden Terhadap Produktivitas Ubi kayu}

Dampak perubahan iklim yang terjadi mempengaruhi produktivitas ubi kayu di Ohoi Wain. Semua responden menyatakan bahwa perubahan iklim menyebabkan produktivitas ubi kayu mereka mengalami penurunan. Penurunan produktivitas terjadi pada tahun 2015. Penurunan produktivitas ubi kayu di Ohoi Wain sebesar $46,4 \%$ atau 7,04 ton per ha per tahun.

Tabel 3. Luas tanam, luas panen, produksi dan produktivitas ubi kayu tahun 2009 - 2018 di Maluku Tenggara.

\begin{tabular}{cccccc}
\hline Tahun & $\begin{array}{c}\text { Luas Areal } \\
\text { Tanam (ha) }\end{array}$ & $\begin{array}{c}\text { Luas Panen } \\
\text { (ha) }\end{array}$ & $\begin{array}{c}\text { Produksi } \\
\text { (ton) }\end{array}$ & $\begin{array}{c}\text { Produktivitas } \\
\text { (ton/ha) }\end{array}$ & $\begin{array}{c}\text { Curah } \\
\text { Hujan }(\mathrm{mm})\end{array}$ \\
\hline 2009 & 56 & 55 & 710 & 12.91 & 2740 \\
2010 & 60 & 55 & 798 & 14.51 & 2809 \\
2011 & 303 & 285 & 4047 & 14.20 & 3018 \\
2012 & 327 & 293 & 3545 & 12.10 & 2399 \\
2013 & 342 & 313 & 4382 & 14.00 & 2825 \\
2014 & 363 & 272 & 3483 & 12.81 & 27.00 \\
2015 & 218 & 176 & 1232 & 12.80 & 1982 \\
2016 & 221 & 178 & 2278 & 12.00 & 2474 \\
2017 & 155 & 137 & 1644 & 12.20 & 2406 \\
2018 & 86 & 69 & 842 & & 2294 \\
\hline
\end{tabular}

Sumber: Data Badan Pusat Statistic Maluku Tenggra. 
Tabel 4. Luas areal tanam dan produksi tahun 20142015 di Ohoi Wain

\begin{tabular}{ccc}
\hline \multirow{2}{*}{$\begin{array}{c}\text { Luas areal tanam } \\
\text { (ha) }\end{array}$} & \multicolumn{2}{c}{ Tahun produksi } \\
\cline { 2 - 3 }$<0,1$ & 2014 & 2015 \\
$0,1-0,2$ & 1,2 ton & 0,5 ton \\
$>0,2$ & 3,2 ton & 0,9 ton \\
\hline
\end{tabular}

Sumber: Data primer diolah 2020

Tabel 5. Total Produksi Dan Produktivitas Ubikayu Tahun 2014 -2015 di Ohoi Wain

\begin{tabular}{ccccc}
\hline Tahun & $\begin{array}{c}\text { Luas } \\
\text { areal } \\
\text { panen } \\
\text { (ha) }\end{array}$ & $\begin{array}{c}\text { Produksi } \\
\text { (ton) }\end{array}$ & $\begin{array}{c}\text { Produktivitas } \\
\text { (ton/ha) }\end{array}$ & $\begin{array}{c}\text { Perubahan } \\
\text { produktivitas } \\
(\%)\end{array}$ \\
\hline 2014 & 5,4 & 82 & 15,18 & - \\
2015 & 5,4 & 44 & 8,14 & $-46,4$ \\
\hline
\end{tabular}

Sumber: Data primer diolah 2020

Para responden menyatakan bahwa penurunan produktivitas ubi kayu tersebut disebabkan karena musim hujan yang tidak bisa ditebak datangnya, dengan musim kemarau yang lebih panjang dalam satu tahun. Selain itu kesuburan tanah menurun serta terjadinya serangan hama yang menurunkan hasil panen ubi kayu mereka.

Di sisi lain, petani menjelaskan bahwa ada beberapa faktor penentu produktivitas ubi kayu di Ohoi Wain, di antaranya ketersediaan lahan pertanian, kesuburan tanah dan umur panen. Hasil penelitian Sugino dan Mayrowani (2009) menunjukkan bawa produktivitas ubi kayu di Lampung dipengaruhi oleh biaya input dan umur panen. Umur panen ubi kayu tidak hanya menentukan produktivitas, namun juga kandungan patinya. Hasil pengamatan di lapangan menunjukkan bahwa petani cenderung memanen ubi kayu lebih awal daripada yang direkomendasikan karena terdesak oleh kebutuhan ekonomi, yang selanjutnya menyebabkan rendahnya produktivitas ubi kayu. Pengaruh umur panen terhadap produktivitas ubi kayu juga dilaporkan oleh Edet et al. (2015) dan Odedina et al. (2015).

Sementara itu, kekeringan juga dilaporkan Sundari dan Yulifianti (2011) sebagai salah satu faktor pembatas pertumbuhan, produksi daun dan umbi ubi kayu. Meskipun lazim ditanam di lahan kering, pertumbuhan tanaman ubi kayu sangat sensitif terhadap kekurangan air. Varietas ubi kayu, kesuburan lahan, fasilitas kredit, hama dan penyakit, dan beberapa karakteristik sosioekonomi juga dilaporkan Ezekiel et al. (2012) sebagai faktor-faktor yang menentukan produktivitas ubi kayu di Nigeria.

Untuk ketersedian lahan pertanian petani menyatakan bahwa lahan yang tersedia untuk budidaya ubi kayu dari tahun ke tahun semakin berkurang akibat dari sistem penggarapan petani berpindah-pindah (setiap tahun buka kebun baru) sehingga meningkatkan lahan kritis tanpa pemberian pupuk untuk mengembalikan kesuburan tanah.

Berkurangnya kesuburan tanah di Ohoi Wain diduga berkaitan dengan sistem pengelolaan lahan yang dikerjakan oleh petani dengan cara tebas bakar pada saat pembukaan lahan sehingga mengurangi kandungan bahan organik tanah. Hal ini sesuai dengan hasil penelitian Chidumayo dan Kwibisa (2003) yang dikutip oleh Hendrikus (2015), menyatakan bahwa pembakaran vegetasi pohon pada pembukaan ladang yang kemudian diikuti dengan praktek peladangan menyebabkan penurunan kandungan bahan organik dan kandungan nitrogen pada lapisan atas tanah. Semakin lama waktu ladang dikerjakan maka berangsur-angsur unsur hara tanah akan cenderung menurun sejalan dengan lamanya waktu ladang dikerjakan.

Secara teknis upaya peningkatan produktivitas ubi kayu dapat ditempuh dengan meningkatkan kualitas teknologi budidaya yang dilakukan petani. Teknologi budidaya ubi kayu secara umum terdiri atas enam jenis teknologi, yaitu (1) penggunaan bibit, (2) metode penanaman, (3) metode pemeliharaan tanaman, (4) metode pemupukan, (5) metode pengolahan lahan, dan (6) metode pengairan. Setiap teknologi tersebut memiliki peranan atau tingkat kepentingan yang berbeda terhadap produktivitas ubi kayu dan dapat dirinci lebih lanjut atas beberapa komponen teknologi. Misalnya, penggunaan bibit dapat dirinci atas penggunaan bibit varietas unggul untuk menjamin potensi produktivitas yang relatif tinggi, tahan hama dan penyakit, dan penggunaan bibit baru untuk menjamin kualitas bibit yang lebih baik.

Pada metode pengendalian hama dan penyakit penggunaan varietas tahan hama dan penyakit juga dianggap memiliki peranan paling penting. Hal ini menunjukkan bahwa untuk meningkatkan produktivitas ubi kayu penggunaan bibit varietas unggul yang berproduktivitas tinggi dan tahan hama dan penyakit merupakan salah satu aspek penting yang harus diperhatikan. Hal itu sesuai dengan studi Hamdani dan Permadi (2015) yang menunjukkan bahwa salah satu faktor yang menyebabkan rendahnya produktivitas ubi kayu adalah masih digunakannya varietas lokal di tingkat petani yang hasilnya jauh lebih rendah daripada potensi hasil beberapa ubi kayu varietas unggul baru (VUB) yang bisa mencapai 40 ton per ha. Namun, hasil pantauan di lokasi penelitian menunjukkan bahwa sebagian besar petani menanam ubi kayu varietas lokal, seperti variatas Bintang Wain, Lislis Jarum, dan Tayando. Varietas ubi kayu unggul yang banyak dibudidayakan di lokasi tersebut adalah varietas Adira. Beberapa studi terdahulu menunjukkan bahwa dominannya varietas ubi kayu lokal tidak hanya terjadi di lokasi penelitian (Maluku Tenggara), namun juga terjadi di provinsi lainnya, seperti Jawa Timur (Heriyanto, 2008) dan Jawa Tengah (Krisdiana, 2016).

Menurut Radjit et al. (2008), penggunaan varietas unggul baru memiliki peranan penting dan strategis karena terkait dengan potensi hasil per satuan luas maupun sebagai salah satu komponen pengendalian 
hama dan penyakit. Sementara menurut Saleh dan Widodo (2007), bibit varietas unggul ubi kayu merupakan salah satu sarana produksi dalam upaya meningkatkan mutu dan produksi tanaman yang akhirnya akan meningkatkan pendapatan petani.

Pada metode pemupukan, komponen teknologi penggunaan pupuk urea dan pupuk organik dianggap paling penting untuk meningkatkan produktivitas ubi kayu. Penggunaan pupuk urea dibutuhkan untuk meningkatkan kesuburan tanah yang umumnya relatif rendah pada lahan kering yang merupakan lahan garapan utama untuk tanaman ubi kayu. Penggunaan pupuk organik terutama dibutuhkan untuk menggemburkan tanah yang relatif keras pada lahan kering, namun seringkali petani terkendala oleh kurangnya ketersediaan pupuk organik.

Menurut Qurrahman et al. (2014), penggunaan lahan kering untuk produksi ubi kayu secara intensif tanpa menerapkan teknik budidaya ubi kayu secara lestari dan berkelanjutan berpotensi menyebabkan kerusakan tanah, sehingga penggunaan pupuk organik sangat penting. Hasil penelitian Mathias dan Kabambe (2015) menunjukkan bahwa penggunaan pupuk organik dapat memperbaiki struktur tanah sehingga memudahkan penetrasi akar dan pembentukan umbi ubi kayu. Demikian pula, nutrisi yang dikandung oleh pupuk organik dilepaskan secara lebih perlahan dan disimpan lebih lama dalam tanah sehingga memungkinkan efek residual yang lebih lama. Walaupun pupuk kandang dan dolomit dapat diganti dengan menambah pupuk urea menjadi $500 \mathrm{~kg} / \mathrm{ha}$, Radjit et al. (2014) menunjukkan bahwa pupuk kandang lebih unggul dari segi perawatan tanah. Menurut Idaryani (2015), salah satu upaya untuk menambah ketersediaan pupuk organik adalah dengan melakukan sistem usaha tani integrasi tanaman ubi kayu dengan ternak.

Pada metode pengolahan tanah, pengolahan tanah secara sempurna dianggap paling penting untuk meningkatkan produktivitas ubi kayu. Hal ini dapat terjadi karena lahan kering yang diusahakan petani untuk tanaman ubi kayu umumnya memiliki lapisan tanah olah yang relatif keras sehingga pengolahan tanah secara baik yang dapat menggemburkan tanah sangat dibutuhkan agar tanaman ubi kayu dapat tumbuh secara optimal. Sementara itu, pada metode pengairan, komponen teknologi yang dianggap paling penting adalah volume pasokan air yang sesuai kebutuhan. Tingkat kepentingan komponen teknologi pengairan tersebut relatif tinggi di Kabupaten Maluku Tenggara karena seluruh pertanaman ubi kayu dilakukan di lahan kering dan sering terjadi kekeringan yang menyebabkan terjadinya penurunan hasil panen. Musim kemarau yang sangat panjang pada waktu penelitian dilakukan menyebabkan tanaman ubi kayu mengalami kekeringan dan tidak optimal produksinya akibatnya umbi ubi kayu menjadi kecil, atau bahkan bias terjadi gagal panen. Untuk mengantisipasi terjadinya kekeringan, disarankan di lokasi tersebut dikembangkan varietas unggul yang toleran kekeringan seperti varietas Malang-6, Malang-4, dan Adira-4. Ketiga varietas tersebut cocok untuk bahan baku industri pati karena berpotensi hasil tinggi dan memiliki kadar pati tinggi, walaupun rasa umbinya pahit (Wahyuni 2015).

\section{Analisis Usahatani Ubi Kayu Terkait Perubahan Iklim}

Analisis pendapatan usaha tani ubi kayu dalam penelitian ini dibedakan menjadi dua, yaitu analisis pendapatan pada tahun 2014 sebagai tahun dengan kondisi iklim mendekati normal dan analisis pada tahun 2015 sebagai tahun dengan kondisi terjadinya pengaruh perubahan iklim (Tabel 7).

\section{Pendapatan petani}

Tabel 8 menunjukkan bahwa pendapatan petani pada tahun 2015 lebih besar dibandingkan dengan pendapatan pada tahun 2014. Presentasi pendapatan pada tahun 2015 mengalami peningkatan sebesar $11,45 \%$ dibandingkan dengan pendapatan pada tahun 2014. Peningkatan pendapatan yang terjadi dikarenakan terjadi kenaikan harga.

Pada tahun 2015, rata-rata harga ubi kayu justru mengalami peningkatan menjadi Rp 120.000,- per bungkus yang semula hanya Rp 50.000 per bungkus pada tahun 2014. Hukum permintaan dan penawaran berlaku disini, bahwa bila persediaan/pasokan/ penawaran barang terbatas atau turun, maka harga barang tersebut akan naik. Jadi kenaikan harga ubi kayu dalam hal ini disebabkan berkurangnya pasokan ubi kayu sebagai akibat dari perubahan iklim.

\section{Kelayakan Usaha Tani Ubikayu}

Untuk mengetahui tingkat kelayakan usaha tani ubi kayu di daerah penelitian digunakan metode Retrun Cost Ratio $(R / C)$, yakni :

$\mathrm{R} / \mathrm{C}=$ Total penerimaan

Total biaya

$=\frac{28.893 .333}{2.633 .333}$

2.633 .333

$=10$

Dapat dilihat dari hasil perhitungan di atas bahwa nilai R/C $10>1$ yang berarti bahwa usahatani ubi kayudi Ohoi Wain layak untuk dikembangkan. Berdasarkan hasil pengamatan di lokasi penelitian bahwa tanaman ubi kayu cocok pada lahan yang memiliki topografi yang datar seperti di Ohoi Wain. Tanaman ubi kayu ini sudah lama dibudidayakan di daerah penelitian. Selain pengaruh topografi, faktor pemeliharaan yang relatif mudah dapat meminimalkan biaya produksi. 
Tabel 7. Rata-rata pendapatan petani tahun 2014 - 2015 di Ohoi Wain

\begin{tabular}{|c|c|c|c|}
\hline \multirow{2}{*}{\multicolumn{2}{|c|}{$\begin{array}{l}\text { Luas } \\
\text { lahan Keterangan } \\
\text { (ha) }\end{array}$}} & \multicolumn{2}{|c|}{ Tahun } \\
\hline & & 2014 & 2015 \\
\hline \multicolumn{2}{|c|}{ Biaya produksi (TC) } & 1.900 .000 & 1.900 .000 \\
\hline \multirow{2}{*}{$<0,1$} & Penerimaan (TR) & 13.000 .000 & 15.120 .000 \\
\hline & Pendapatan $\quad(\mathrm{Rp})$ & 11.100 .000 & 13.220 .000 \\
\hline \multirow{3}{*}{$0,1-0,2$} & Biaya produksi (TC) & 2.500 .000 & 2.500 .000 \\
\hline & Penerimaan $\quad(\mathrm{TR})$ & 26.400 .000 & 28.800 .000 \\
\hline & Pendapatan & 23.900 .000 & 26.300 .000 \\
\hline \multirow{3}{*}{$>0,2$} & Biaya produksi (TC) & 3.300 .000 & 3.300 .000 \\
\hline & Penerimaan (TR) & 43.000 .000 & 47.040 .000 \\
\hline & Pendapatan (Rp) & 39.700 .000 & 43.740 .000 \\
\hline
\end{tabular}

Sumber: Data primer diolah, 2020

Tabel 8. Total pendapatan usaha tani ubi kayu tahun 2014-2015 di Ohoi Wain

\begin{tabular}{ccccc}
\hline Tahun & $\begin{array}{c}\text { Biaya } \\
\text { total } \\
\text { (Rp.) }\end{array}$ & $\begin{array}{c}\text { Penerimaan } \\
\text { (Rp.) }\end{array}$ & $\begin{array}{c}\text { Pendapatan } \\
\text { (Rp.) }\end{array}$ & $\begin{array}{c}\text { Perubahan } \\
\text { Pendapatan } \\
(\%)\end{array}$ \\
\hline 2014 & 2.633 .333 & 27.466 .666 & 24.900 .000 & - \\
2015 & 2.633 .333 & 30.320 .000 & 27.753 .333 & $-11,45$ \\
\hline
\end{tabular}

Sumber: Data primer diolah, 2020.

\section{KESIMPULAN}

Kesimpulan-kesimpulan dari penelitian ini adalah sebagai berikut:

1. Sebagian besar petani ubi kayu di Ohoi Wain, Kecamatan Kei Kecil Timur, Kabupaten Maluku Tenggara, mengetahui adanya perubahan iklim. Unsur perubahan iklim yang paling dirasakan oleh petani dan dominan mempengaruhi produksi ubi kayu adalah curah hujan dan suhu. Ada beberapa faktor yang turut menentukan produktivitas ubi kayu di Ohoi Wain, di antaranya ketersediaan lahan pertanian, kesuburan tanah dan umur panen.

2. Perubahan iklim yang terjadi menyebabkan petani melakukan upaya untuk meminimalkan kehilangan hasil. Upaya yang dilakukan petani dalam penelitian ini adalah: pengolahan tanah minimum untuk mengurangi evaporasi karena permukaan tanah terbuka, mengubah waktu tanam, melakukan pemilihan variatas tanaman yang unggul dan toleran terhadap cekaman kekeringan dan berumur pendek, serta pemberian mulsa organik.

3. Perubahan iklim yang ditandai dengan penurunan curah hujan menyebabkan produktivitas ubi kayu yang semula mencapai 15,18 ton per ha pada tahun 2014 turun menjadi 8,14 ton per ha di tahun 2015 , atau terjadi penurunan produksi sebesar 46,4\%. Namun, kondisi sebaliknya terjadi pada pendapatan petani, yaitu rata-rata pendapatan petani yang semula mencapai Rp 24.900.000 pada tahun 2014 meningkat menjadi Rp 27.753.333 pada tahun 2015, atau peningkatan pendapatan sebesar $11,45 \%$.

\section{DAFTAR PUSTAKA}

Anwar, M.R., D.L. Liu, R. Farquharson, I. Macadam, A. Abadi, J. Finlayson, B. Wang and T. Ramilan. 2015. Climate change impacts on phenology and yields of five broadacre crops at four climatologically distinct locations in Australia. Agricultural Systems 132:133-144. DOI: http://dx.doi.org/10.1016/j.agsy.2014.09. 010.

Edet, M.A., H. Tijani-Eniola, S.T.O. Lagoke and G. Tarawali. 2015. Relationship of cassava growth parameters with yield, yield related components and harvest time in Ibadan, Southwestern Nigeria. J. Nat. Sci. Res. 5(9):87-92.

Ezekiel, A.A., S.O. Olawuyi, M.O. Ganiyu, I.K. Ojedokun and S. Adeyemo. 2012. Effects of climate change on cassava productivity in ilesa east local government area, Osun State, Nigeria. British Journal of Arts and Social Sciences. 10(2):153-162.

Heriyanto. 2008. Preferensi petani dan penyebaran varietas unggul ubikayu di Jawa Timur. Agritek. 17(06):19-28.

IPCC. 2007. Climate Change 2007 - Impacts, Adaptation and Vulnerability. Contribution of Working Group II to the Fourth Assessment Report of the IPCC. Cambridge university Press. New York.

Idaryani. 2015. Teknologi produksi ubi kayu melalui sistem integrasi tanaman-ternak sebagai sumber bahan baku bioethanol. Prosiding Seminar Nasional Hari Pangan Sedunia Ke-34 "Pertanian-Bioindustri Berbasis Pangan Lokal Potensial" 2014 , Makassar. p.491-499. Badan 
Penelitian dan Pengembangan Pertanian, Jakarta.

Krisdiana, R. 2016. Penyebaran, preferensi, dan kontribusi ekonomi varietas unggul ubikayu di Jawa Tengah. Prosiding Seminar Hasil Penelitian Tanaman Aneka Kacang dan Umbi 2015, Malang. p.561-568. Pusat Penelitian dan Pengembangan Tanaman Pangan, Badan Penelitian dan Pengembangan Pertanian, Jakarta.

Laimeheriwa, S. 2014. Analisis tren perubahan curah hujan pada tiga wilayah dengan pola hujan yang berbeda di Provinsi Maluku. Jurnal Budidaya Pertanian 10(2):71-78.

Mathias, L. dan V.H. Kabambe. 2015. Potential to increase cassava yields through cattle manure and fertilizer application: results from Bunda College, Central Malawi. Afr. J. Plant Sci. 9(5):228-234. DOI: https://doi.org/10.5897/ AJPS2014.1237

Muchtadi, T.R. dan Sugiyono. 1992. Ilmu Pengetahuan Bahan Pangan. Departemen Pendidikan dan Kebudayaan. Direktorat Jendral Pendidikan Tinggi. Pusat Antar Universitas. Institut Pertanian Bogor. Bogor.

Qurrahman, B.F.T., A. Suriadikusuma dan R. Haryanto. 2014. Analisis potensi kerusakan tanah untuk produksi ubi kayu (Manihot utilisima) pada lahan kering di Kecamatan Tanjungsiang, Kabupaten Subang. J Agro 1(1):22-32. DOI: https://doi.org/10.15575/78

Ruminta, Handoko dan T. Nurmala. 2018. Indikasi perubahan iklim dan dampaknya terhadap produksi padi di Indonesia (Studi kasus:
Sumatera Selatan dan Malang Raya). Jurnal Agro 14:48-60. DOI: https://doi.org/10.15575/ 1607

Radjit, B.S., N. Saleh, Subandi dan E. Ginting. 2008. Teknologi produksi ubi kayu mendukung industri bioetanol. Buletin Palawija 16:57-66.

Saleh, N. dan Y. Widodo. 2007. Profil dan peluang pengembangan ubi kayu di Indonesia. Buletin Palawija 14:69-78.

Suciantini. 2015. Interaksi iklim (curah hujan) terhadap produksi tanaman pangan di Kabupaten Pacitan. Prosiding Seminar Nasional Masyarakat Biobiversitas Indonesia 1(2):358-365. DOI: $10.13057 / \mathrm{psnmbi} / \mathrm{m} 010232$

Sundari T. dan R. Yulifianti. 2011. Karakteristik agronomis dan fisiko-kimia ubi kayu umur genjah. Penelitian Pertanian Tanam Pangan. 30(3):210-218.

Tapotubun, E., 2012. Kandungan Gizi Dan Masa Simpan Makanan Tradisional "Enbal" Asal Kepulauan Kei dengan Penambahan Tepung Ikan Layang. Tesis. Sekolah Pascasarjana, Institut Pertanian Bogor, Bogor.

Thamrin, M., A. Mhardiyah dan S.E. Marpaung. 2013 Analisis usaha tani ubi kayu (Manihot utillisima). Agrium 18: 57-63.

Wahyuni, T.S. 2015. Pertumbuhan tanaman dan toleransi aksesi ubi kayu pada kondisi kekeringan. Prosiding Hasil Penelitian Tanaman Aneka Kacang dan Umbi Tahun 2014. p.747759. Pusat Penelitian dan Pengembangan Tanaman Pangan, Badan Penelitian dan Pengembangan Pertanian, Jakarta. 